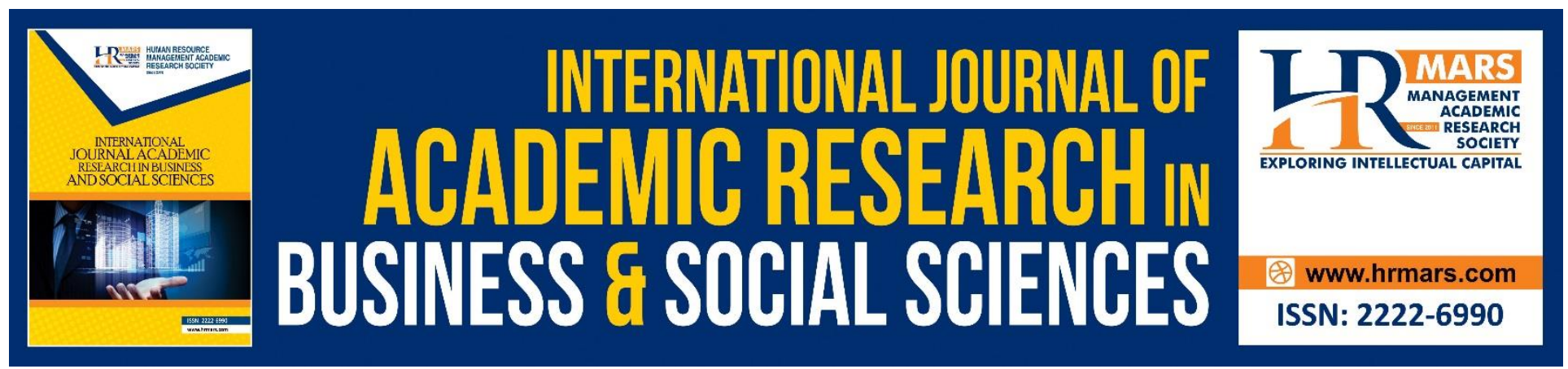

\title{
A Review of International Trade and Ghana's Economic Growth Amidst the Covid-19 Pandemic
}

Dwumfour Emmanuel Yamoah, Weiqing Li

To Link this Article: http://dx.doi.org/10.6007/IJARBSS/v10-i9/7856

DOI:10.6007/IJARBSS/v10-i9/7856

Received: 05 June 2020, Revised: 09 July 2020, Accepted: 18 August 2020

Published Online: 28 September 2020

In-Text Citation: (Yamoah, \& Li, 2020)

To Cite this Article: Yamoah, D. E., \& Li, W. (2020). A Review of International Trade and Ghana's Economic Growth Amidst the Covid-19 Pandemic. International Journal of Academic Research in Business and Social Sciences. 10(9), 651-659.

\section{Copyright: (C) 2020 The Author(s)}

Published by Human Resource Management Academic Research Society (www.hrmars.com)

This article is published under the Creative Commons Attribution (CC BY 4.0) license. Anyone may reproduce, distribute, translate and create derivative works of this article (for both commercial and non-commercial purposes), subject to full attribution to the original publication and authors. The full terms of this license may be seen

at: http://creativecommons.org/licences/by/4.0/legalcode

Vol. 10, No. 9, 2020, Pg. 651 - 659

http://hrmars.com/index.php/pages/detail/IJARBSS

JOURNAL HOMEPAGE

Full Terms \& Conditions of access and use can be found at http://hrmars.com/index.php/pages/detail/publication-ethics 


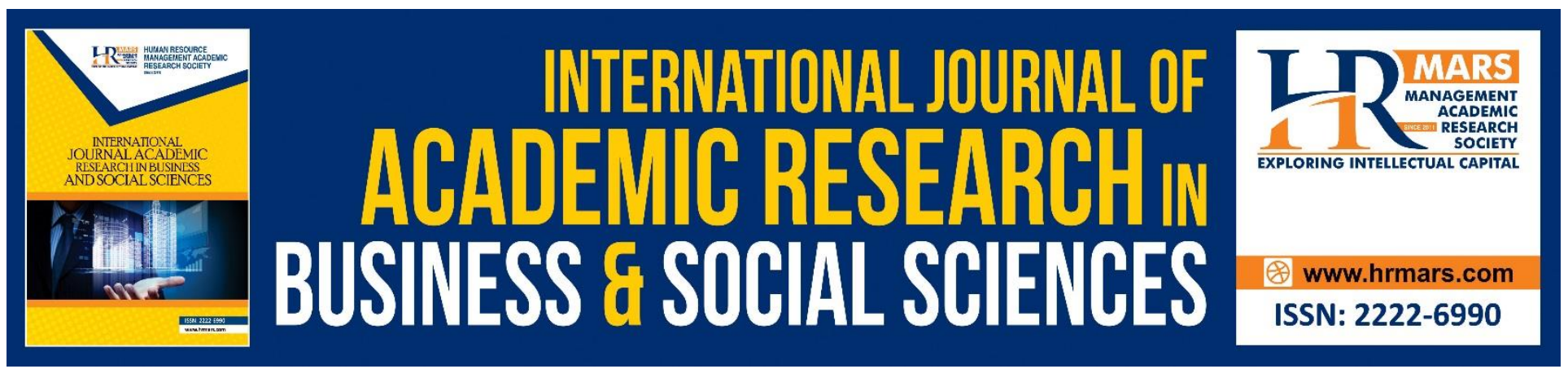

\title{
A Review of International Trade and Ghana's Economic Growth Amidst the Covid-19 Pandemic
}

\author{
Dwumfour Emmanuel Yamoah, Weiqing Li \\ School of International Economics and Tourism Management, Zhejiang International Studies \\ University, Hangzhou 310023, China. \\ Email: 88924381@163.com
}

\begin{abstract}
International trade has been a major bedrock of global economy and almost every country depends on it. Ghana, a developing country, is no different from countries that rely heavily on international trade. The COVID-19 pandemic that has hit the world lead to almost every country closing its borders, resulting in a halt of trade between countries. Among the major trading partners of Ghana are China, USA, India, Netherlands, and South Africa. All of these countries have placed restrictions on traveling due to the outbreak and this is anticipated to negatively affect trade. The purpose of this study is to assess the possible impact of the COVID-19 pandemic on the relationship between international trade and Ghana's economic growth. The aim of the study is achieved through reviewing of existing literature.
\end{abstract}

\section{Introduction}

The economy of Ghana had experienced expansion in 2019, accounting for a real Gross Domestic Product growth of $7.1 \%$. Ghana has consistently been recognized in the to 10 fastest growing economies in Africa due to its high growth drive since 2017. The progress within the macroeconomic setting followed with growth in domestic demand as a result of increased private consumption. According to the African Development Bank, the industrial sector experiencing an average annual growth of more than $10 \%$, seemed to have been the stimulus for growth over the three years preceding 2019 was a major driver of growth in the three years to 2019 (African Development Bank, 2020).

Ghana's economy is set to take a hit as its growth was lowered to $0.9 \%$ while its budget deficit is expected to more than double according to the Finance Minister, Ken Ofori-Atta. This projection is as a result of a fall in oil prices and the effects of the COVID-19 pandemic, which has affected several aspects of the economy locally and internationally.

The forecast is grim reading for Ghana which had recorded GDP growth of at least six percent for the last three years and was expected to keep its budget deficit below five percent for a third year (Mbewa, 2020). According to Ofori-Atta, the doubling of the budget deficit is calculated at 11.4 
INTERNATIONAL JOURNAL OF ACADEMIC RESEARCH IN BUSINESS AND SOCIAL SCIENCES Vol. 10, No. 9, 2020, E-ISSN: 2222-6990 @ 2020 HRMARS

percent of gross domestic product compared with a projection of 4.7 percent at the end of 2019. Economic growth was predicted to be at 6.8 percent this year and was subsequently revised to 1.5 percent in March with the onset of the coronavirus pandemic.

The COVID-19 pandemic is estimated to significantly affect global economy negatively. Amidst this, leaders of various countries all over the world have put in place diverse fiscal strategies to Governments around the world are implementing various fiscal measures to lessen the adverse impact of the pandemic and support for households and firms.

The Minister of Finance for Ghana on 30 March 2020, delivered a presentation to the Parliament on the "Economic Impact of the COVID-19 pandemic on the Economy of Ghana". The Minister of state submitted to the lawmakers the anticipated effect COVID-19 was going to have on the economy of the country and the various measures Government has put in place to allay the impact.

The purpose of this study is to predict the impact of the COVID-19 pandemic on Ghana's economy from the perspective of previous studies.

1. The study will discuss the previous trend of Ghana's international trade

2. The paper will explore how the trends in international trade have been interrupted by the pandemic.

3. In making up for these interruptions, the government has put in place certain measures and this study will assess the level at which these measure mitigate or otherwise the disruptions caused by the pandemic.

\section{Before COVID-19}

\section{Ghana's Economic Outlook}

The economy of Ghana 's economy constantly grew up unto 2019. The GDP for the first quarter was projected at $6.7 \%$, parallel to $5.4 \%$ in the first quarter of 2018 . Growth not owing to oil also recorded a $6.0 \%$ growth. The seemingly high growth experienced quarterly was propelled by aggressive recovery within the service industry which had experienced a growth of $7.2 \%$ paralleled to $1.2 \%$ in 2018 (The World Bank, 2019).

The country's executive persisted with consolidation of its fiscal efforts in 2019 amidst difficulties in achieving the targeted revenue. The performance of fiscal measures within the first part of 2019 exhibited a total deficit in budget of 3.3\% of GDP, which was higher than anticipated, $2.9 \%$ of GDP. This can be attributed to the decline in revenue of $1.6 \%$ of GDP, more than expenditure cuts of $1 \%$ of GDP.

The current account of Ghana in the first part of 2019 was projected to achieve a surplus of $0.1 \%$ of GDP augmented by satisfactory trade conditions of the top three commodities it exports; oil, gold and cocoa, leading to a trade surplus of $2.8 \%$ of GDP. The surplus accounted for in the current account, coupled with substantial financial and capital accounts inflows, lead in a total BOP surplus approximately $1.9 \%$ of GDP. The issuance of a USD3 billion Eurobond in March 2019, lead to a significant improvement in Ghana's International Reserves (GIR) of \$8.6 billion in 2019, which is paralleled to 4.3 months of import cover at the end of June 2019.

The country's currency, Ghana cedi, experienced some amount of pressure in the first half of 2019, owing to increase in demand, as importers aimed to replenish their stock, however, in the second quarter of the year, the domestic currency market became fairly serene. 
INTERNATIONAL JOURNAL OF ACADEMIC RESEARCH IN BUSINESS AND SOCIAL SCIENCES Vol. 10, No. 9, 2020, E-ISSN: 2222-6990 @ 2020 HRMARS

\section{Imports, Exports, and Ghana's Economic Growth}

According to OEC World (2018), Ghana was ranked $71^{\text {st }}$ and $84^{\text {th }}$ in total export and import respectively in the world. Ghana in 2018 had a total export of $\$ 20.5 \mathrm{~b}$ and an import value of $\$ 14.9 \mathrm{~b}$, leading to positive balance of trade, $\$ 5.64 \mathrm{~b}$. In the same year, the country experienced a per capita of $\$ 689$ and $\$ 499$ for export and import respectively. Table 1.0 shows the top products exported and imported by Ghana as at 2018. Ghana imports from and exports to a number of destinations and Table 2.0 shows the top five countries Ghana imports to and exports from.

Table 1.0: Top Exports and Imports of Ghana (2018)

\begin{tabular}{lll}
\hline \multicolumn{1}{c}{ Export } & & \\
\hline \multicolumn{1}{c}{ Product } & Total Value (\$) \\
\hline Gold & $10 \mathrm{~B}$ & \\
Crude Petroleum & $4.65 \mathrm{~B}$ \\
Cocoa Beans & $1.78 \mathrm{~B}$ \\
Cocoa Paste & $489 \mathrm{M}$ \\
Coconuts, Brazil Nuts, and Cashews & $424 \mathrm{M}$ \\
\hline Import & \\
\hline Refined Petroleum & $738 \mathrm{M}$ \\
Cars & $466 \mathrm{M}$ \\
Rice & $425 \mathrm{M}$ \\
Non-fillet Frozen Fish & $303 \mathrm{M}$ \\
Delivery Trucks & $274 \mathrm{M}$ \\
\hline
\end{tabular}

Source: OEC World

Table 2.0: Top Exports and Imports Destinations of Ghana (2018)

\begin{tabular}{lll}
\hline \multicolumn{1}{c}{ Export } & & \\
\hline \multicolumn{1}{c}{ Country } & Total Value (\$) \\
\hline India & $5.18 \mathrm{~B}$ & \\
Switzerland & $3.33 \mathrm{~B}$ \\
China & $2.25 \mathrm{~B}$ \\
South Africa & $1.6 \mathrm{~B}$ \\
United Arab Emirates & $1.17 \mathrm{~B}$ \\
\hline Import & & \\
China & $4.36 \mathrm{~B}$ \\
United States & $810 \mathrm{M}$ \\
Netherlands & $745 \mathrm{M}$ \\
India & $738 \mathrm{M}$ \\
United Kingdom & $559 \mathrm{M}$ \\
\hline
\end{tabular}

Source: OEC World

According to Workman (2020), considering it from a continental angle, $48 \%$ of exports from Ghana in terms of value were dispensed to countries in Asian, whereas $31.4 \%$ was exported to European countries. Ghana further exported $15 \%$ worth of products to African countries. North American 
INTERNATIONAL JOURNAL OF ACADEMIC RESEARCH IN BUSINESS AND SOCIAL SCIENCES Vol. 10, No. 9, 2020, E-ISSN: 2222-6990 @ 2020 HRMARS

countries received 4.3\% worth of goods, Latin America (aside Mexico) 1.2\%, and Ocean's New Zealand and Australia receiving $0.1 \%$.

A study conducted by Boakye and Gyamfi (2017) found a positive relationship between exports and Gross Domestic Product in Ghana. According to their findings, an increase of $1 \%$ in the remittance per capita subsequently results in a $10.8 \%$ rise in Gross Domestic Product. From the analysis presented, trade, in terms of exports and imports plays a huge role in the sustenance and subsequent growth of Ghana's economy.

\section{Ghana's Foreign Direct Investment Inflows}

Borensztein et al (1998) in their study found that FDI influence on growth is dependent on the availability of human resources. They also found that foreign investment contributes to growth more than local investment and has the ability of increasing domestic investment. Li \& Liu (2005) used random effects model and 3 SLS on 21 developed countries and 63 developing from 1970-1999. The study affirms the need for human resource availability in order to ensure relation between FDI and economic growth. Though Bengoa \& Sanchez (2003) agrees the previous studies, they further states that a significant level of a stable economy and a more liberalized capital market also ensures the positive influence of FDI on growth.

A general observation of the net inflows of FDI trends shows that Ghana has improved following the establishment of GIPC in 1994. From 1994 to 2005 net inflows fell within the range of \$58 million to $\$ 250$ million. In 2002, Ghana hit the lowest value of FDI net inflows, which was $\$ 58.93$ million. This may be attributed to the era where Ghana had to join HIPC because it was highly indebted and could not pay its debts. This did not show a good indication of a conducive atmosphere for investment. FDI net inflow increase in 2006 at $\$ 636.010$ million and further increased until 2008 where it reached $\$ 2.715$ billion, which ia about 326.89\% increase from the 2006 value. In 2009, FDI net inflows declined to $\$ 2.373$ billion. FDI net inflows to Ghana hit its highest so far in 2016 where it reached $\$ 3.485$ billion, after which it declines to $\$ 3.255$ billion showing a 6.6\% decline from 2016 (Owusu, 2019).

The 2020 World Investment Report provided by UNCTAD indicated inflow of foreign direct investment to Ghana declined from $\$ 3 M$ to $\$ 2.3 \mathrm{M}$ between 2018 and 2019. Foreign Direct Investment stock recorded $\$ 38.5 \mathrm{M}$ in 2019 . The two main industries that attracted a large portion of the FDI inflow were the oil and mining. As part of the activities Ghana undertakes in an attempt to lure foreign investors into the country, the Ghana Investment Summit, an annual event, is organized. This is done in an attempt to position itself as the hub of investment within the sub region. According to Santander Trade Market (2020), China registers the highest number of investment projects with institutions by Ghanaian. India, the United Kingdom, South Africa, Turkey, Mauritania and France closely follow China.

For emerging value chain, FDI and portfolio investments serves as low-cost capital. Ghana being the highest recipient of foreign direct invests inflow within the West African sub region, it enjoyed approximately more than a third of the inflows within the region in 2018, echoing it's emerging skill base. The novel Business Regulatory Reform agenda introduced by the government was estimated to mobilize domestic revenue and enhance the business setting. Digital investments, particularly within the financial sector, is expected to rise giving support to efficiency (African Development Bank, 2020). Studies on the directional causality of FDI and Economic growth lead to different findings. Hansen \& Rand (2006) found a bi-directional causality between Foreign Direct Investment and Economic Growth. Meaning that FDI causes Growth and growth causes FDI. This was agreed by Omri, Nguyen 
INTERNATIONAL JOURNAL OF ACADEMIC RESEARCH IN BUSINESS AND SOCIAL SCIENCES Vol. 10, No. 9, 2020, E-ISSN: 2222-6990 @ 2020 HRMARS

\& Rault (2014). Basem \& Abeer (2011) however found a unidirectional causality from GDP to FDI which indicates that the growth of the domestic economy attracts FDI inflows. Ugwegbe \& Okore (2013) supports these findings but Sunday \& Ango (2017) establish a unidirectional causality from FDI to economic growth indicating that FDI causes Growth and not the other way around.

\section{Discussion}

Economic growth is anticipated to dawdling considerably this year. Low international demand for oil and low price of oil will exert some amount of weight on the external sector, while measures taken domestically to contain the pandemic couple with layoffs will hit hard on local demands. Unstable prices of commodity and a likely lengthy outbreak are downside risks. Economic indicators such as Real Gross Domestic Product growth, and real Gross Domestic Product per capita growth are expected to decrease considerably according to the African Development Bank economic outlook report.

As presented in the country's 2020 mid-year budget, cutting of fiscal deficit is estimated to end the years 2019 and 2020 at $4.5 \%$ and $4.7 \%$ respectively, after effectively trimming it down from $7.3 \%$ of GDP in 2016 to 3.9\% in 2018. In as much as these estimates are higher than projected, they still fall within the remit of the Fiscal Responsibility Act. Presenting the budget, the country's Minister in charge of finance attributes the evolving burden on the fiscal balance to a number of factors including dip in anticipated revenue (approximately 16\%), government financing of flagship programmes and offloading of bonds held by non-residents as a result of developing security difficulties from the Sahel region.

There is an increasing fear about the rising debt stock even though the measures government has put in place to manage the debt has helped in slowing the rate at which it was increasing. In addition to the increase in debt stock, the cost of both domestic and external borrowing have speedily amplified, responsible for approximately a quarter of the sum of expenditure and about $45 \%$ of tax revenue. Further, the current cleanup within the banking industry added approximately $\mathrm{C} 13 \mathrm{~B}$ to the debt stock, moving it from $57.4 \%$ of GDP to $60.5 \%$ of GDP as at September 2019. Whereas the latest rebasing exercise led to a dip in the debt-to-GDP ratio, interest payment as a percentage of tax revenue, which demonstrates the country's repayment ability, remains unchanged.

The supplementary budget for 2020 submitted by Ghana's Minister of Finance indicated, irrespective of the COVID-19 pandemic, the government is pressing on with medium-term strategic plans, amidst relatively more significant difficult economic circumstances cropping up as a result of the pandemic. Specifically, the revenue for government is estimated to decline abruptly from and estimated ¿67.1Billion as started in the 2020 budget to $\$ 53.7 B$ Billion, representing a $20 \%$ decline. Government's expenditure on the contrary is estimated to rise by approximately $c 11.8 B i l l i o n$, from a projected amount of $\$ 84.5$ Billion in the initial 2020 budget to $\$ 96.3$ Billion, representing $13.7 \%$ increase.

Under normal circumstance, foreign investment, international trade, and the like would have mitigated the rise in expenditure and debt. All of these have declined significantly due to closure of international boarders of many countries, prominent among them are those countries Ghana does business with.

The impact of the pandemic will further hit hard the economy in that even will effective medical and social measure are put in place to arrest the situation, like in China, the country's economy will find it difficult getting on its feet. With the impact that comes with high inflation, if steps are not taken to arrest the current situation, a huge gab will be seen in core inflation rate and headline inflation. This 
INTERNATIONAL JOURNAL OF ACADEMIC RESEARCH IN BUSINESS AND SOCIAL SCIENCES Vol. 10, No. 9, 2020, E-ISSN: 2222-6990 @ 2020 HRMARS

will intend affect, negatively, anticipated economic growth for both the first and second quarters. The economy is likely to show some loopholes in its road to recovery. Both empirical and theoretical studies have given varied conclusions concerning the trend of effect inflation will have on economic growth.

\section{Investment}

The likely effect of COVID-19 pandemic on the investment environment in Ghana might be immense. These impacts are be experienced as a result of a dip in estimated portfolio investment and FDI, a congestion in the financial system domestically, capital flight, and less avenues of funding from foreign sources. Earlier in the year, the United Nations Conference on Trade and Development (UNCTAD) projected global foreign direct investment will drop by $5 \%$ to $15 \%$ in 2020 owing to the COVID-19 pandemic. The dread of foreign direct investment declining is heightened by the fact that the top 5,000 Multinational Companies (MNCs) have already, on average, modified their revenue approximations downhill by $9 \%$. MNCs in developing economies are likely to be the worse affected. Profit has since been estimated to decline by $16 \%$. Subsequently, a fall in the revenue of MNCs would automatically lead to a fall in foreign investment considering reinvestment of profit is a major part of FDI.

On a more fascinating note, quiet a number of the top trading countries of Ghana are her major sources of foreign direct investment. In the year 2018, China topped the countries with investment inflows to Ghana with 37 projects. India (18 projects), the Netherlands (15 projects) and the United Kingdom (12 projects) followed China. Considering investments in terms of the value of the dollar, Netherlands invested a sum of $\$ 1.89 \mathrm{~B}$ and was the leading country from which investment came from into Ghana. The Netherlands was followed by India with an investment value of $\$ 510.72 \mathrm{M}$. Considering how hard these countries have also been hit by the pandemic, investment in to Ghana is expected to decline. This is likely to result in the inflow falling below \$2.8 net foreign direct investment the country had experienced in 2019. Taking the projected percentage dip in foreign direct investment as estimated by UNCTAD, $5 \%$ to $15 \%$, Ghana will intern bag approximately $\$ 2.4 \mathrm{~B}$ $\$ 2.7 \mathrm{~B}$, which falls short of the 2019 figure.

The uneasiness associated with pandemic and subsequently the lockdown exercise further exacerbates the global economic risk, leading to decline in international portfolio investments and remittances to develop economies including Ghana. In 2019, Ghana received US\$2.6 billion in net portfolio investments. Throughout the period of the pandemic, portfolio investments inflow into developing countries would decrease and there is a more possibility of capital reversals with investors in developed countries pursuing liquidity to help them adjust to the economic meltdown in their home economies. In this light, it is anticipated that the economy of Ghana might be negatively affected through dip in inflows of portfolio. Remittances encompasses 3.6\% of the country's GDP and this is likely to decline; though this might be compensated for by the countercyclical nature of inflow of remittance.

\section{Conclusion}

The current global situation with the COVID-19 pandemic can be seen as a torn in world economies as every country including large economies such as Germany, China, US, Norway, France, and the like have all experienced a shake up in their economies. Various industries with economies have practically been brought to a halt. 
INTERNATIONAL JOURNAL OF ACADEMIC RESEARCH IN BUSINESS AND SOCIAL SCIENCES Vol. 10, No. 9, 2020, E-ISSN: 2222-6990 @ 2020 HRMARS

In the first five months of 2020, Ghana recorded a reduction in imports and exports trade, which is predominantly caused by the pandemic. The reduced economic activity on the domestic front has led to a decline in imports and exports. By the close of the first quarter of 2020, total balance of payment summed up to a surplus of $\$ 1.48$ Billion, representing approximately $49 \%$ of the balance of payment recorded in the first quarter of 2019. The mid-year budget submitted by the Finance Minister indicated the country's gross international reserves is $\$ 9.17$ billion, equivalent to 4.3 months of import cover. In as much as the COVID-19 pandemic has had a negative effect of the global economy with Ghana not being an exception, the situation in the country does not look bad as might have been anticipated.

The review made by the current study shows that the possible revenue loss in impacted economies would be considerably significant, with global gross domestic product reducing to $3.9 \%$. Emerging economies are more likely to be affected most as it is anticipated they might experience a $4 \%$ decline on the average, with some hovering a little over $6.5 \%$. To ease the strain this will have, it is proposed that governments would have to offer substantial support to affected households and businesses.

This review is likely an underestimation of the impending economic impact of the outbreak. Further studies could explore areas such as the exact negative impact of financial shock, and uncertainty driven demands.

The purpose of the study was to explore international trade and Ghana's economy amidst the current global pandemic, using previous studies. Theoretically, this study will lay the grounds for further empirical studies, in which real data will be gathered to test the claims made by this paper. This review will add to previous studies that have raised a number of factors affecting international trade and economic development in Africa, pandemics. Practically, this review will give an idea to policy makers and on the areas currently suffering as a result of the pandemic. With this knowledge, other areas of the economic will be strengthened in order to make up for the downturn in international trade.

\section{References}

African Development Bank. (2020). Ghana Economic Outlook. Retrieved on 2th August 2020 from https://www.afdb.org/en/countries/west-africa/ghana/ghana-economic-outlook

Basem, M. L., \& Abeer, A. (2011). The Impact of Foreign Direct Investment On Economic Growth in Jordan. IJRRAS, 8(2), 253-258

Bengoa, M., \& Sanchez. (2003). Foreign direct investment, economic freedom and growth: New evidence from Latin America, European Journal of Political Economy, 19 (3): 529-545

Boakye, R. N., \& Gyamfi, E. (2017). The impact of foreign trade on the economic growth of Ghana. International Journal of Business Marketing an Management 2(3), 20-26

The World Bank, (2019). The World Bank in Ghana. Retrieved on $1^{\text {st }}$ August 2020 from https://www.worldbank.org/en/country/ghana/overview

Borensztein, E., De Gregorio, J., \& Lee, J-W., (1998),. How Does Foreign Direct Investment Affect Economic Growth?, Journal of International Economics, 45 (1), 115-135.

Hansen, H., \& Rand, J. (2006). On the causal links between FDI and growth in developing countries. World Economy, 29 (1): $21-41$

Li, X., Liu, X. (2005). Foreign Direct Investment and economic growth: An increasingly endogenous relationship. World Development, 33 (3): 393-407 
INTERNATIONAL JOURNAL OF ACADEMIC RESEARCH IN BUSINESS AND SOCIAL SCIENCES

Vol. 10, No. 9, 2020, E-ISSN: 2222-6990 @ 2020 HRMARS

Omri, A., Nguyen, D. K., \& Rault, C. (2014). Causal interactions between CO2 emissions, FDI and economic growth: Evidence from dynamic simultaneous-equation models, Economic Modeling, 42: 382-389

Owusu, A. K. J. (2019). Impact of foreign direct investment on economic growth in Ghana. University of Ghana, Legon.

Santander Trade Market. (2020). Ghana: Foreign Investment. Retrieved on $4^{\text {th }}$ August 2020 from https://santandertrade.com/en/portal/establish-overseas/ghana/investing

Sunday, G., \& Ango, Y. I. (2017). Analysis of the Impact of Foreign Direct Investment on Economic Growth in Nigeria. International Journal of Operational Research in Management, Social Sciences and Education, 3(2), 88- 100.

Workman, D. (2020). Ghana's Top 10 Exports. Retrieved on $1^{\text {st }}$ August 2020 from http://www.worldstopexports.com/ghanas-top-10-exports/

Mbewa, D. O. (2020). Ghana's economic growth projection lowered to 0.9\%: minister. CGTN Africa, July 23 